\title{
Changes in occurrence and abundance of northern/southern flatfishes over a 20 -year period in a coastal nursery area (Bay of Vilaine) and on the eastern continental shelf of the Bay of Biscay
}

\author{
YVES DÉSAUNAY ${ }^{1}$, DANIEL GUÉRAULT ${ }^{1}$, OLIVIER LE PAPE ${ }^{2}$ \\ and JEAN-CHARLES POULARD ${ }^{1}$
}

${ }^{1}$ IFREMER, Département Ecologie et modèles pour l'halieutique, rue de l'ile d'Yeu, B.P. 21102, 44311 Nantes, France. E-mail: Yves.Desaunay@ifremer.fr

${ }^{2}$ Pôle Halieutique, Agrocampus Rennes, 65 rue de St Brieuc, CS 84215, 35042 Rennes, France.

SUMMARY: Several works have demonstrated trends in the distribution of fish species relative to global warming. This study investigated whether similar trends have occurred for selected flatfish species on the continental shelf of the Bay of Biscay. These species were used as indicators and changes in their populations were studied in a coastal nursery ground where flatfish juveniles are concentrated as well as on the entire shelf. Previous studies analysing changes in sea surface temperature for the continental shelf indicate that winter warming occurred in the 1980s and 1990s. Sixteen autumn cruises conducted since 1981 in the Bay of Vilaine nursery area and 11 autumn cruises since 1987 over the entire shelf provided data on a nearly annual basis for the abundance of benthic fish. The four most common flatfish species were selected and their occurrence and yearly abundance were analysed with regard to specific biogeographic ranges and climate change. Similar results were obtained for juveniles on a nursery scale and for all age groups on the entire shelf. Although sole (Solea solea) showed irregular yearly variations, northern winter spawners such as plaice (Pleuronectes platessa) and dab (Limanda limanda) exhibited significantly high abundance during the 1980s, followed by a continuing low level and ultimately zero catches. On the other hand, the wedge sole (Dicologoglossa cuneata), a southern summer spawner, showed an increasing trend in the late 1990s.

Keywords: flatfish, spatial distribution, ocean warming, Bay of Biscay.

RESUMEN: CAMBIOS EN LA APARICIÓN Y ABUNDANCIA DE ESPECIES DE PECES PLANOS DURANTE UN PERIODO DE 20 AÑOS EN

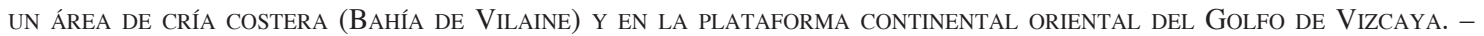
Diversos trabajos han demostrado tendencias en la distribución de especies de peces relacionadas con el calentamiento global. Este estudio se investigó si han ocurrido tendencias similares en especies seleccionadas de peces planos en la plataforma continental del Golfo de Vizcaya. Esas especies fueron usadas como indicadores y los cambios en sus poblaciones fueron analizados tanto en un área costera de concentración de juveniles como en toda la plataforma. Estudios previos de los cambios en la temperatura superficial del mar en la plataforma continental, indican la ocurrencia de periodos de calentamiento de invierno en los años 1980s y 1990s. 16 campañas de otoño realizadas desde 1981 en el área de crecimiento de la Bahía de Vilaine y 11 campañas de otoño efectuadas desde 1987 en toda la plataforma continental proporcionaron datos en una base casi anual de la abundancia de peces bentónicos. Se seleccionaron las cuatro especies de peces planos más comunes y su presencia y abundancia anual fueron analizadas con respecto a sus rangos biogeográficos específicos y al cambio climático. Se obtuvieron resultados similares para los juveniles en su área de crecimiento y para todos los grupos de edad a escala de toda la plataforma continental. Aunque el lenguado (Solea solea) mostró variaciones anuales irregulares, la solla (Pleuronectes platessa) y la limanda (Limanda limanda) que se reproducen en invierno mostraron una abundancia significativamente más alta durante los 1980 s, seguida de una disminución continua y por último capturas nulas. Por el contrario, el lenguadillo (Dicologoglossa cuneata), que se reproduce en el sur durante el verano, mostró una tendencia al incremento a finales de los 1990 s.

Palabras clave: peces planos, distribución espacial, calentamiento del océano, Golfo de Vizcaya. 


\section{INTRODUCTION}

Demersal fish assemblages on the continental shelf of the Bay of Biscay have been analysed from catches of professional trawlers (1979-1993) by Poulard and Léauté (2002) and scientific survey data (1987-2000) by Poulard et al. (2003). Both studies indicate the relative stability of fish communities in the medium term. However, marine communities exhibit long term changes in the context of a persistent increase of the ocean heat: in coastal systems, seagrasses have been and will continue to be modified (Short and Neckles, 1999), while the distribution of open ocean planktonic communities has exhibited northward shifts (Beaugrand et al., 2002).

Climatic changes affect marine fish to differing degrees. Rare warm water species have been recorded along the Cornish coast of the UK by Stebbing et al. (2002), who reported an increase in such observations after 1985. On a wider geographical and temporal scale, Quéro et al. (1998) have noted a northward extension of "rare" tropical fishes along the continental slope since 1963, which they attribute to the warming of the European Atlantic waters. As the waters of the southern Bay of Biscay show a significant increase in the sea surface temperature (a mean rise of $1.4^{\circ} \mathrm{C}$ for the period 1972-1993 according to Koutsikopoulos et al. (1998), progressive changes may be expected in the distribution of demersal fish in the shallow part of the continental shelf. The present study provides a preliminary analysis of surface temperature in the northern (and broader) part of the Bay of Biscay (Fig. 1) and then investigates changes in the specific distribution and abundance of four selected flatfishes.

Two data sources were used: (i) coastal nursery ground surveys carried out in the Bay of Vilaine over a 20-year period (Désaunay et al., 1981, Le Pape et al., 2003), which show a temporal trend in flatfish juvenile abundance; and (ii) groundfish surveys conducted by Ifremer on the eastern continental shelf of the Bay of Biscay since 1987 (Poulard et al., 2003), which provide species abundance indices.

\section{MATERIAL AND METHODS}

\section{Sea surface temperature (SST) in the northern Bay of Biscay for the two last decades}

Mean SST values, computed per period of 10 days, were extracted from the Météo-France data base from 1981 to 1998 for an area located between $46^{\circ} \mathrm{N}$ and $47^{\circ} 20^{\prime} \mathrm{N}$, and $2^{\circ} \mathrm{W}$ and $3^{\circ} \mathrm{W}$. Three different values were analysed: annual mean SST and minimum and maximum annual values.

\section{Selection of species}

Data were available over the whole period for four species: the common sole (Solea solea, Linné, 1758), the plaice (Pleuronectes platessa, Linné, 1758), the dab (Limanda limanda, Linné, 1758) and the wedge sole (Dicologoglossa cuneata, Moreau 1881). Other flatfishes such as solenette, scaldfish, flounder, brill and turbot were too scarce to provide reliable abundance indices.

According to the general descriptions by Wheeler (1978) and Whitehead et al. (1986), the Bay of Biscay corresponds roughly to the centre of geographical distribution of common sole and plaice, but marks the southern limit of cold-temperate species such as dab and the northern limit for the warm-temperate wedge sole.

However, these distributions are rather theoretical or based on old data. Plaice, for example, has never been caught during bottom-trawl surveys in recent years along the northwestern Mediterranean (Bertrand, pers. com., from MEDITS cruises), although Fischer et al. (1987) report its presence along the Mediterranean coast of Spain. Moreover, plaice was never found in the Sado estuary (Portugal) by Cabral (2000), who carried out an extensive inventory of the flatfish community and identified three tropical flatfishes for the first time in those waters. Hence, the Bay of Biscay now seems to be closer to the southern limit than to the centre of plaice distribution.

\section{Chronology and sampling protocol for the surveys in the Bay of Vilaine}

This area of $330 \mathrm{~km}^{2}$, covered with soft sediments, extends from the estuary of the Vilaine river to a depth of $35 \mathrm{~m}$ (Fig. 1). Specific abundance estimates were extracted from a database collecting the results of almost yearly beam-trawl surveys performed in the Bay of Vilaine. Sixteen autumn cruises were carried out from 1981 to 2001 (all years except 1991, 1994, 1995, 1998 and 1999). The gear used, a 3-metre beam trawl without a chain ahead of the foot rope and with a $20-\mathrm{mm}$ stretched mesh at the codend, was hauled at 2.5 


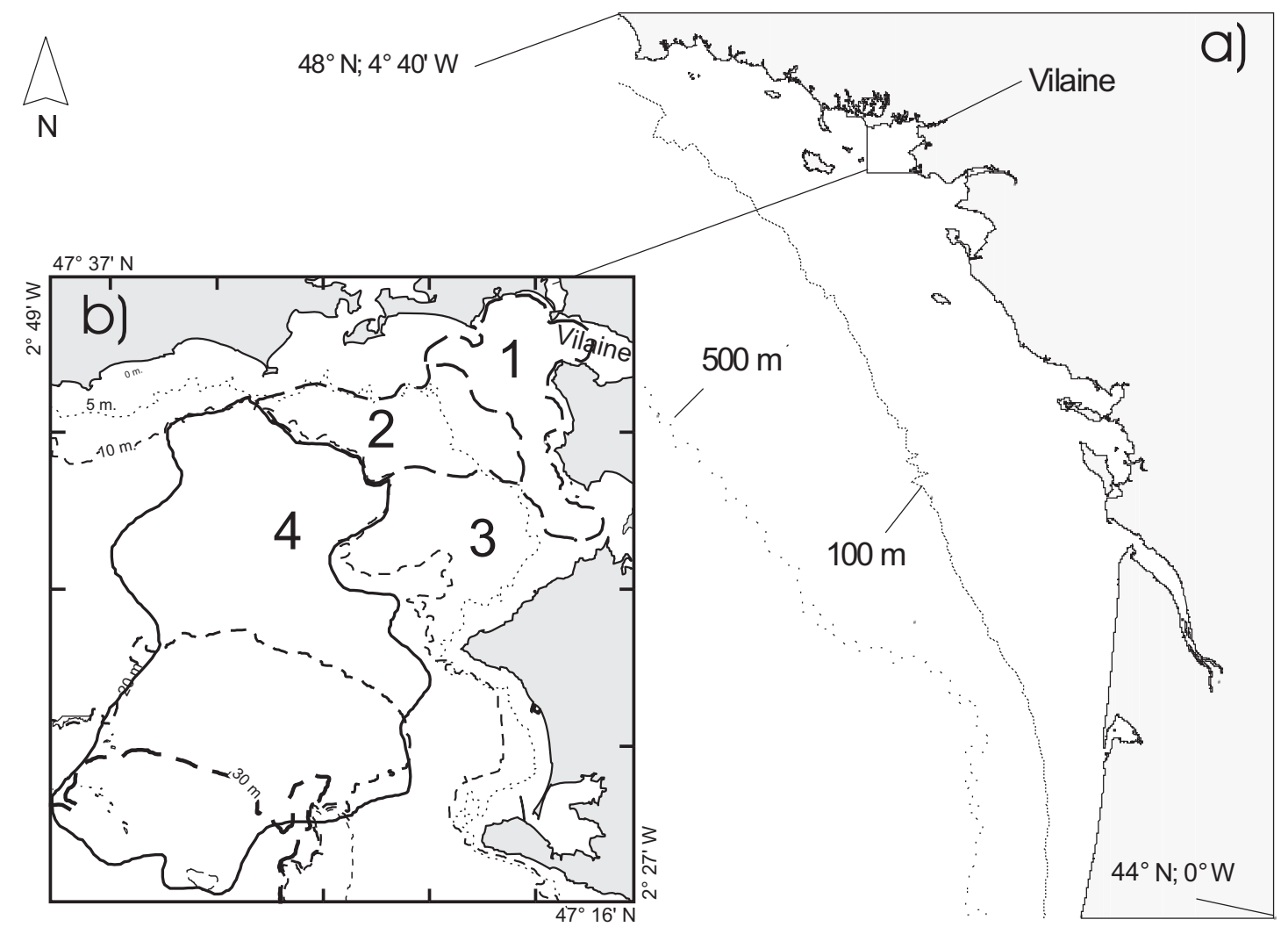

FIG. 1. - a, Map of the Bay of Biscay, showing the coastline, the 100 and $500 \mathrm{~m}$ isobaths, and the location of the bay of Vilaine; b, Map of the Bay of Vilaine, showing the coastline, the 5,10,20 and $30 \mathrm{~m}$ isobaths and the limits of the four sampling strata

knots for 20 min. An average of 45 trawl stations were included in each cruise. The sampling protocol relied upon a 4-stratum scheme (Fig. 1), in which strata were identified by depth range and sediment type (Le Pape et al., 2003).

As the bias due to selectivity with a $20-\mathrm{mm}$ mesh size is negligible in autumn for the 0-group of winter spawner species (size range is $7-15 \mathrm{~cm}$ for plaice, 6-9 $\mathrm{cm}$ for dab, and 6-14 $\mathrm{cm}$ for sole); these 0-group abundances were estimated without correction. For wedge sole, which spawns in summer, most of 0group fish under $9 \mathrm{~cm}$ in length escaped through the codend, so this species is better estimated by the 1+2-groups (size range: 12 to $24 \mathrm{~cm}$ ). Separation into age groups was done from the size composition of the catch, either by a hiatus between 0-group and 1-group, or by otolith examination.

The occurrence of each species was expressed as the relative number (in \%) of positive hauls in a survey. Abundance estimates were based on the number of individuals caught per stratum according to Pennington and Grosslein (1977) relative to the stratified sampling scheme of the survey, i.e. estimated density for each stratum was multiplied by area size, and the total number of individuals was estimated as the sum of these four strata.

Thus, data provide information on the success of regional spawning and colonisation of the nursery by young-of-the-year fish.

\section{Data from groundfish surveys over the eastern part of the Bay of Biscay shelf}

Data were collected during the eleven groundfish surveys carried out by Ifremer in the Bay of Biscay (Fig. 1) from October to December since 1987 (Amara et al., 1998; ICES, 1997; Souissi et al., 2001). The survey area was located between $48^{\circ} 30^{\prime} \mathrm{N}$ in the north and the northern edge of the "Gouf de Cap Breton" in the south. The sampling scheme was stratified according to latitude and depth, and a 36/47 GOV trawl with a $20 \mathrm{~mm}$ mesh codend liner was used. Hauls were run for $30 \mathrm{~min}$, with a towing speed of 4 knots. Fishing was mainly limited to daylight hours. Catch weights and catch numbers were recorded for all species, all finfish and a selection of shellfish were measured. About 130 to 70 hauls per survey provided data on the 


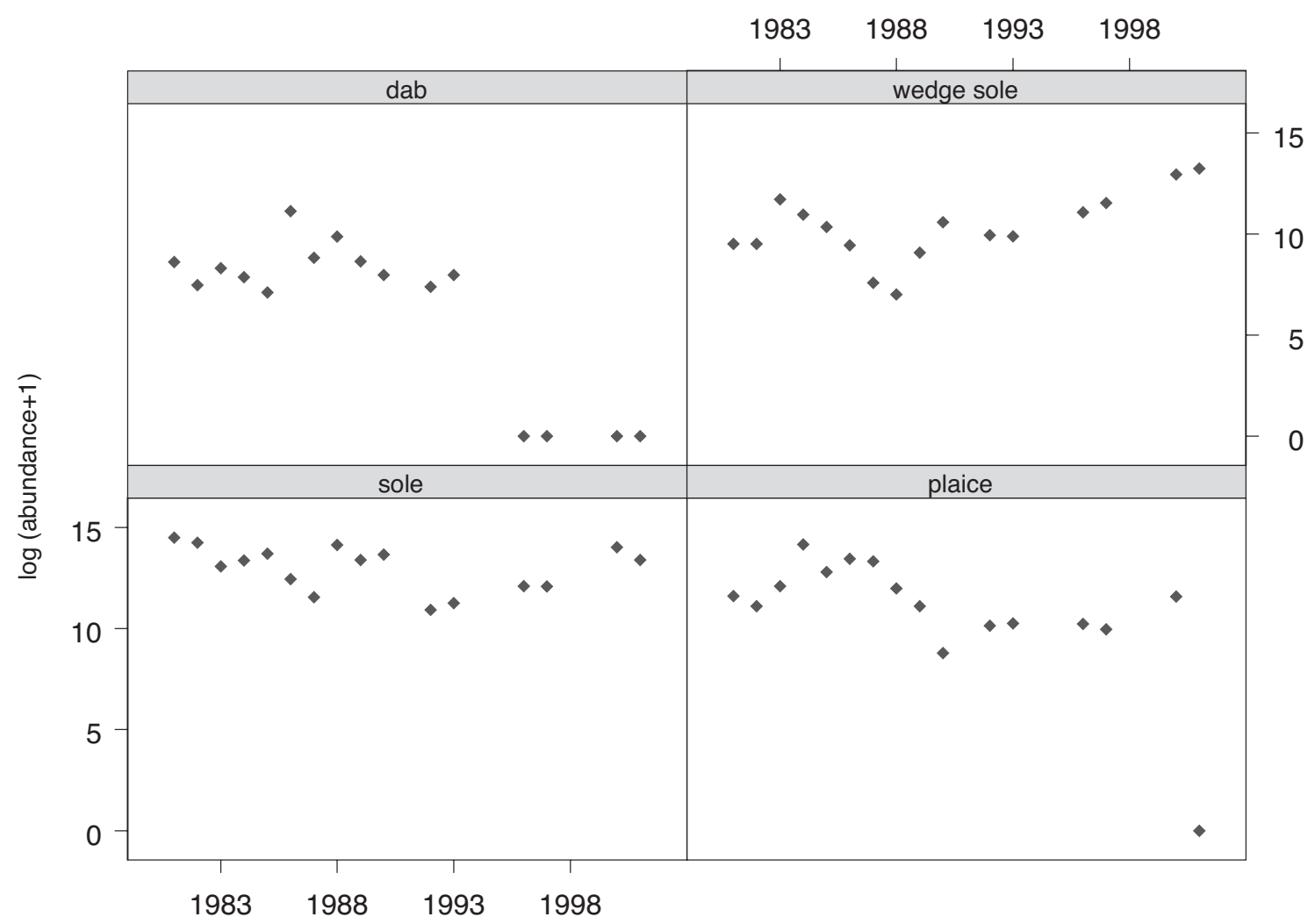

FIG. 2. - Time series of the log-transformed juvenile abundances for four flatfish species in the Bay of Vilaine nursery ground from 1981 to 2001.

occurrence and abundance of the selected species. Abundance was given by the mean number of individuals per trawl, and the occurrence of each species was expressed as the relative number (in \%) of positive hauls in a survey. As age composition for the studied species was not available from this survey, all year classes were pooled.

\section{Data analysis}

A Kendall correlation test was used to check for correlation between the year (used as a descriptor) and the response variables ( 3 SST indices and 8 annual abundance indices). This non-parametric method was chosen because of the non-linear trends between the year and the studied response variables.

\section{RESULTS}

\section{Sea surface temperature trends in the northern Bay of Biscay}

Kendall correlation tests showed no trend in mean and maximum SST, but an increase in the minimum SST (positive correlation, $\mathrm{a}=2 \%$ ) in the northern Bay of Biscay. This indicates warming of SST on the continental shelf in winter, but no trend in SST for the other seasons.

\section{Yearly occurrence and abundance in the Bay of Vilaine}

The selected flatfishes were quite common at the cruise level: the common sole, plaice, dab and wedge sole were recorded respectively on $16,15,12$ and 16 cruises out of 16 . The analysis of juvenile abundance in the Bay of Vilaine nursery ground showed significant differences between species according to their biogeographical distribution (Fig. 2, Tables 1 and 3).

Northern species (plaice and dab) showed a significant decrease during the study period and totally disappeared from the area in the most recent years (the last 4 surveys for the dab and the last survey for the plaice). However, the abundance of the southern species (wedge sole) increased significantly. The Bay of Biscay is at the biogeographical centre of the sole distribution, which probably explains why recruitment fluctuations were lower than for the other species and no trend was found for juvenile abundance. 
TABLE 1. - Occurrence ( $\%$ of positive hauls) and abundance index (estimated in thousands of individuals for selected species in the bay of Vilaine.

\begin{tabular}{|c|c|c|c|c|}
\hline & $\begin{array}{l}0 \text {-group } \\
\text { sole }\end{array}$ & $\begin{array}{l}\text { 0-group } \\
\text { plaice }\end{array}$ & $\begin{array}{c}0 \text {-group } \\
\text { dab }\end{array}$ & $\begin{array}{l}\text { 1+2-groups } \\
\text { wedge sole }\end{array}$ \\
\hline \multicolumn{5}{|c|}{ occurrence } \\
\hline 1981 & 88.0 & 48.0 & 16.0 & 8.0 \\
\hline 1982 & 93.3 & 33.3 & 6.7 & 23.3 \\
\hline 1983 & 86.7 & 55.6 & 8.9 & 44.4 \\
\hline 1984 & 72.2 & 63.9 & 8.3 & 47.2 \\
\hline 1985 & 55.6 & 25.0 & 2.8 & 27.8 \\
\hline 1986 & 51.1 & 46.8 & 48.9 & 14.9 \\
\hline 1987 & 45.8 & 83.3 & 29.2 & 4.2 \\
\hline 1988 & 83.7 & 42.9 & 22.4 & 4.1 \\
\hline 1989 & 56.5 & 34.8 & 8.7 & 21.7 \\
\hline 1990 & 72.5 & 9.8 & 2.0 & 19.6 \\
\hline 1992 & 40.0 & 23.6 & 3.6 & 9.1 \\
\hline 1993 & 23.5 & 19.6 & 2.0 & 7.8 \\
\hline 1996 & 42.1 & 26.3 & 0 & 36.8 \\
\hline 1997 & 31.3 & 14.6 & 0 & 20.8 \\
\hline 2000 & 54.5 & 36.4 & 0 & 72.7 \\
\hline 2001 & 65.9 & 0 & 0 & 70.7 \\
\hline \multicolumn{5}{|c|}{ abundance } \\
\hline 1981 & 1984 & 110 & 5.5 & 14 \\
\hline 1982 & 1535 & 67 & 1.8 & 14 \\
\hline 1983 & 473 & 178 & 4.0 & 123 \\
\hline 1984 & 641 & 1409 & 2.6 & 58 \\
\hline 1985 & 895 & 358 & 1.2 & 31 \\
\hline 1986 & 252 & 692 & 68.2 & 13 \\
\hline 1987 & 104 & 611 & 6.8 & 2 \\
\hline 1988 & 1366 & 159 & 19.5 & 1 \\
\hline 1989 & 660 & 66 & 5.7 & 9 \\
\hline 1990 & 857 & 7 & 2.9 & 40 \\
\hline 1992 & 56 & 26 & 1.6 & 21 \\
\hline 1993 & 77 & 28 & 2.9 & 20 \\
\hline 1996 & 178 & 28 & 0 & 65 \\
\hline 1997 & 177 & 21 & 0 & 102 \\
\hline 2000 & 1227 & 107 & 0 & 420 \\
\hline 2001 & 652 & 0 & 0 & 562 \\
\hline
\end{tabular}

These results were confirmed by similar occurrence trends for these four species.

\section{Yearly occurrence and abundance over the Bay of Biscay shelf}

Although wedge sole was caught every year, even in low numbers, plaice was observed only on 8 cruises out of 11 and dab on 6 cruises (Table 2). Changes in occurrence and abundance (Fig. 3 and table 3) for the plaice and dab (a marked decrease in the 1990s) were contrary to those for the wedge sole (higher catches from 1997 onwards). For these three species the trends were similar to those observed for juvenile abundance in the Bay of Vilaine, confirming the decreased occurrence and abundance of northern species. No plaice were caught during the last three surveys and no dab during the last five surveys.

Figure 3 shows a clear increase of catches for the common sole. However, both data sets indicate the
TABLE 2. - Occurrence (\% of positive hauls) and abundance index (mean number of fish caught per 30-min haul) for selected species in the Bay of Biscay.

\begin{tabular}{|c|c|c|c|c|}
\hline & $\begin{array}{l}0 \text {-group } \\
\text { sole }\end{array}$ & $\begin{array}{l}\text { 0-group } \\
\text { plaice }\end{array}$ & $\begin{array}{l}\text { 0-group } \\
\text { dab }\end{array}$ & $\begin{array}{l}1+2 \text {-groups } \\
\text { wedge sole }\end{array}$ \\
\hline \multicolumn{5}{|c|}{ occurrence } \\
\hline 1987 & 9 & 8 & 6 & 2 \\
\hline 1988 & 14 & 4 & 4 & $\overline{5}$ \\
\hline 1989 & 11 & 6 & 6 & 2 \\
\hline 1990 & 10 & 5 & 6 & 5 \\
\hline 1992 & 9 & 6 & 3 & 6 \\
\hline 1994 & 13 & 7 & 1 & 10 \\
\hline 1995 & 15 & 3 & 0 & 10 \\
\hline 1997 & 19 & 3 & 0 & 12 \\
\hline 1998 & 11 & 0 & 0 & 12 \\
\hline 1999 & 16 & 0 & 0 & 10 \\
\hline 2000 & 20 & 0 & 0 & 10 \\
\hline \multicolumn{5}{|c|}{ abundance } \\
\hline 1987 & 0.43 & 0.95 & 0.93 & 0.16 \\
\hline 1988 & 0.73 & 0.56 & 0.46 & 0.28 \\
\hline 1989 & 0.20 & 0.60 & 0.03 & 0.06 \\
\hline 1990 & 0.32 & 0.18 & 0.45 & 0.27 \\
\hline 1992 & 0.40 & 0.17 & 0.22 & 0.29 \\
\hline 1994 & 1.37 & 0.48 & 0.01 & 0.49 \\
\hline 1995 & 1.09 & 0.09 & 0 & 0.38 \\
\hline 1997 & 1.65 & 0.06 & 0 & 5.0 \\
\hline 1998 & 2.02 & 0 & 0 & 0.75 \\
\hline 1999 & 0.97 & 0 & 0 & 0.60 \\
\hline 2000 & 1.96 & 0 & 0 & 1.81 \\
\hline
\end{tabular}

TABLE 3. - Variation rate of the annual index, slope sign, and significance of the Kendall correlation between the year and the abundance index for selected flatfish species in the Bay of Vilaine nursery area and on the entire Bay of Biscay shelf.

\begin{tabular}{lccc}
\hline & Variation rate (\%) & Slope sign & a (in \%) \\
\hline Bay of Vilaine & & & \\
Sole (0-group) & 83 & - & $<1$ \\
Plaice (0-group) & 166 & - & 1 \\
Dab (0-group) & 219 & + & $<5$ \\
Wedge sole (1/2 groups) & 173 & & \\
Bay of Biscay & & + & 2 \\
Sole (all groups) & 65 & - & 0.01 \\
Plaice (all groups) & 113 & + & 0.1 \\
Dab (all groups) & 159 & & \\
Wedge sole (all groups) & 157 & & \\
\hline
\end{tabular}

same trend on a nursery ground scale for the recent period (1987 to 2000).

\section{DISCUSSION}

\section{Hydroclimatic conditions over the Bay of Biscay and local effects}

Koutsikopoulos et al., (1998) described longterm warming of the sea surface in the southeastern part of the Bay of Biscay, which was mainly sig- 


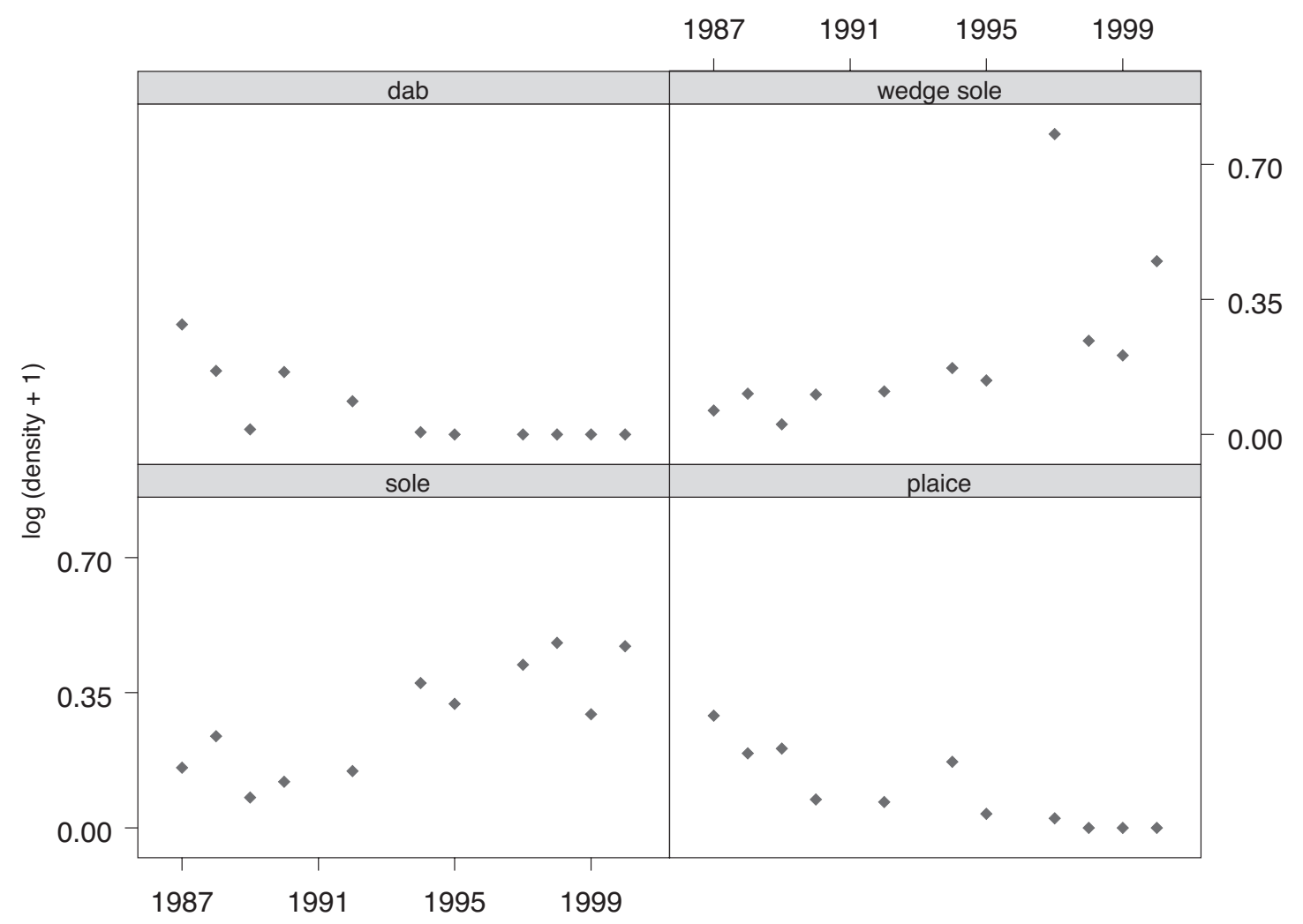

FIG. 3. - Time series of the log-transformed densities for four flatfish species in the Bay of Biscay from 1987 to 2000.

nificant for winter months. Planque et al., (2003) confirmed a warming trend in the southern part of the Bay of Biscay (up to a $0.6^{\circ} \mathrm{C}$ increase per decade from 1971 to 1998), but not in the northern part. The present study also indicates that the increase in sea temperature is lower in the northern part, but that a significant warming of winter temperatures does occur there: the continental shelf of the Bay of Biscay, broader in the north, is also affected by winter warming. This is consistent with the large-scale increase in sea temperature in the northeast Atlantic, balanced by a shift toward a colder equilibrium in the sub-Arctic Gyre (Beaugrand et al., (2002).

Environmental forcings on a regional scale are likely to affect fish life cycles and thus their distribution and abundance. For sole in the northern Bay of Biscay, yearly fluctuations in abundance are driven by local forcings, mainly by fluvial discharge (Le Pape et al., 2003). Regional conditions such as the Poleward Current and upwelling events are responsible for the variable larval success of megrims (Lepidorhombus whiffjagonis and L. boscii) in the southern Bay of Biscay (Cantabrian Sea; Sanchez et al., 2001). Moreover, demersal and benthic fish communities exhibit variations under the same influences (Sanchez et al., 2001). Thus, hydrological changes may affect populations either temporarily through recruitment processes or more permanently through adult distribution and spawning.

\section{Climatic conditions versus timing of spawning and juvenile growth}

Analysis of flatfish abundance showed parallel development of juveniles in the Bay of Vilaine and of the whole population studied on the continental shelf. Dab and plaice became scarce and then disappeared from catches, whereas wedge sole became more abundant and widespread.

Species such as plaice and dab, which are winter spawners at the boundary of their distribution area in the Bay of Biscay, are more sensitive to oceanic winter warming. Etel Bay $\left(47.35^{\circ} \mathrm{N}, 03.15^{\circ} \mathrm{W}\right)$, the southernmost nursery area for dab noted in 1976 and 1977, was no longer productive in September 2002 (Désaunay, pers. comm.). Conversely, the growth and survival of early juvenile wedge sole may be favoured by winter warming in the Bay of Biscay. The common sole, which has its centre of distribution in the Bay of Biscay, is more sensitive to local habitat changes than to slight warming. As indicated 
by Philippart et al. (1998), climatic effect may induce recruitment variations in combination with a latitudinal effect.

A comparable effect was noted by Welleman et al. (2001), who considered that a northward shift in spatial distribution of the common sole in the North Sea might be induced by a temperature increase. Moreover, Fox et al. (2000) confirmed a negative relationship between winter sea temperature and the year-class strength of plaice around the British Isles and in the North Sea. A similar relationship has been demonstrated for dab in the Bristol Channel by Henderson (1998), who showed a negative effect of temperature on 0-group growth.

Benefits and drawbacks resulting from a warming trend are species-specific. In freshwater fish, Shuter and Post (1990) showed that long periods of cold waters have a greater negative effect on smaller fish. Reciprocally, this is in accordance with the increase in smaller Soleidae (wedge sole and also the solenette Buglossidium luteum not described in the present study) and the decrease in large Pleuronectidae (plaice and dab) related to winter warming.

According to the concept of Pauly (1994) concerning the dominance of smaller flatfish species in tropical waters, a long-term global warming in temperate regions would probably result in higher occurrence of small flatfish species. Thus, special attention should be paid to smaller fish species such as solenette, scaldfish and topknot, which are not usually surveyed.

Solea senegalensis, a southern Soleidae considered as a rare fish in the Bay of Biscay by Quéro et al. (1980) and initially described there by Lagardère et al. (1979), might be expected to occur more frequently in this area. Although this species could exhibit the same northern extension as the wedge sole, its distribution is actually limited to around $46^{\circ} \mathrm{N}$. Catches in our surveys remained very uncommon, perhaps because this "sole" is heavily exploited in coastal areas during the summer spawning period.

\section{CONCLUSION}

A continuous warming trend in Bay of Biscay waters is likely to result in a long-term change in demersal fish biogeography. Beaugrand et al., (2002) emphasised the serious consequences of such a scenario for the entire marine ecosystem, particularly for fisheries. The same risk may apply to other ecosystems around the world, as described and simulated by Peterson et al. (2002) for Mexican faunas.

Species at the boundary of their distribution ranges need to be carefully observed through surveys conducted in coastal and shelf habitats. Wheeler (1978) has clearly warned that "there is every likelihood that extensions or modifications to the range of many species will be noted in time". Rogers et al. (1998), at the end of their analysis of demersal fish communities around the UK, stressed the impact of zoogeography for the British Isles, which are at the boundary between boreal fauna and Lusitanean fauna, and expressed a need for comparable studies in more southern regions. The Bay of Biscay, an intermediate area, would seem propitious for surveying changes in the fish community.

\section{ACKNOWLEDGEMENTS}

Sea water temperature data were provided by the French agency of meteorology Météo France. The authors wish to thank all the scientists and R.V. crews involved in the cruises. Special thanks to O. Berthelé and P. Beillois for their contribution to this paper. They are also grateful to the reviewers and to James Gray for his efficiency in improving the English text .

\section{REFERENCES}

Amara, R., J.-C. Poulard, F.Lagardère and Y. Désaunay. - 1998. Comparison between the life cycles of two Soleidae, the common sole, Solea solea, and the thickback sole, Microchirus variegatus, in the Bay of Biscay (France). Environ. Biol. Fish., 53: 193-209.

Beaugrand, G., P.C. Reid, F. Ibanez, J.A. Lindley and M. Edwards. - 2002. Reorganization of North Atlantic Marine Copepod Biodiversity and Climate. Science, 296: 1692-1694.

Cabral, H.N. - 2000. Distribution and abundance patterns of flatfishes in the Sado estuary, Portugal. Estuaries, 23: 351-358.

Désaunay, Y., J.-B. Pérodou and P. Beillois. - 1981. Etude des nurseries de poissons du littoral de la Loire Atlantique. Science et Pêche, Bull. Inst. Pêches Marit., 319: 1-23.

Fischer, W., M.-L. Bauchot and M. Schneider. - 1987. Fiches FAO d'identification des espèces pour les besoins de la pêche. (Révision 1). Méditerranée et Mer Noire Zone de pêche, 37, FAO.

Fox, C.J., B.P. Planque and C.D., Darby. - 2000. Synchrony in the recruitment time-series of plaice (Pleuronectes platessa L.) around the United Kingdom and the influence of sea temperature. J. Sea Res., 44: 159-168.

Henderson, P.A. - 1998. On the variation in dab Limanda limanda recruitment: a zoogeography study. J. Sea Res., 40: 131-142.

ICES - 1997. Report of the International Bottom Trawl Survey Working Group. CM 1997 /H:6.

Koutsikopoulos, C., P. Beillois, C. Leroy and F. Taillefer. - 1998. Temporal trends and spatial structures in the bay of Biscay. 
Oceanol. Acta, 21: 335-344.

Lagardère, F., P. Descamps and J.-C. Quéro. - 1979. Discovery along the coast of the Charente-Maritime of a population of Solea senegalensis Kaup, 1858 (Soleidae, Pleuronectiformes). Ann. Soc. Sci. Nat. Charent-Marit., 6: 563-572.

Le Pape, O., Y. Désaunay and D. Guérault. - 2003. Relationship between fluvial discharge and sole (Solea solea L.) recruitment in the bay of Biscay. ICES Mar. Sci. Symp., 219: 241-248.

Pennington, M.R. and M.D. Grosslein. - 1977. Accuracy of abundance indices based on stratified random trawl surveys. ICNAF Res. Doc., 78/VI/77: 1-41.

Peterson, A.T., M.A. Ortega-Huerta, J. Bartley, V. SanchezCordero, J. Soberon, R.H. Buddmeier and D.R.B. Stockwell 2002. Future projections for Mexican faunas under global climate change scenarios. Nature, 416 (6881): 626-629.

Philippart, C.J.M., P.A. Henderson, T. Johanessen, A.D. Rijnsdorp, and S.I. Rogers. - 1998. Latitudinal variation in fish recruits in Northwest Europe. J. Sea Res., 39: 69-77.

Planque, B., P. Beillois, A.-M. Jégou, P. Lazure, P. Petitgas and I. Puillat. -2003 . Large scale hydroclimatic variability in the bay of Biscay. The 1990s in the context of interdecadal changes. ICES Marine Science Symposia. 219: 61-70.

Poulard, J.-C., J.-P.Léauté. - 2002. Interaction between marine populations and fishing activities: temporal patterns of landings of La Rochelle trawlers in the Bay of Biscay. Aquat. Living Resour., 15: 197-210.

Poulard, J.-C., F. Blanchard, J. Boucher and S. Souissi. - 2003. Variability in the demersal fish assemblages of Bay of Biscay during the 90s. ICES Marine Science Symposia. 219: 411-414.

Quéro, J.-C., P. Descamps, M. Duron, J. Fonteneau and R. Verron. - 1980. Ichthyiological observations realized in 1979. Ann. Soc. Sci. Nat. Charent-Marit., 6(7): 697-705.

Quéro, J.-C., M.-H. Buit (du) and J.-J. Vayne. - 1998. The records of tropical fishes and the warming of the European Atlantic waters. Oceanol. Acta. 21(2): 345-351.

Rogers, S.I., A.D. Rijnsdorp, U. Damm and W. Vanhee. - 1998. Demersal fish populations in the coastal waters of the UK and continental NW Europe from beam trawl survey data collected from 1990 to 1995. J. Sea Res. 39: 79-102.

Sanchez, F. and A. Sarrano. - 2003. Variability of groundfish communities of the Cantabrian Sea during the1990s. ICES Marine Science Symposia. 219: 249-260.

Sanchez, R., F. Sanchez, J. Landa and A. Fernandez. - 2003. Influence of oceanographic parameters on recruitments of megrim (Lepidorhombus whiffjagonis) and four-spot megrim (L. boscii) in the northern spanish continental shelf (ICES division VIIIC). ICES Marine Science Symposia. 219: 400-402.

Short, F.T. and H.A. Neckles. - 1999. The effects of global climate change on seagrasses. Aquat. Botan., 36(3-4): 169-196.

Shuter, B.J. and J.R. Post. - 1990. Climate, population viability, and the zoogeography of temperate fishes. Trans. Amer. Fish. Soc. 119(2): 314-336.

Souissi, S., F. Ibanez, R. Ben Hamadou, J. Boucher, A.C. Cathelineau, F. Blanchard and J.-C. Poulard. - 2001. A new multivariate mapping method for studying species assemblages and their habitats: example using bottom trawl surveys in the Bay of Biscay (France). Sarsia, 86: 527-542

Stebbing, A.R.D., S.M.T. Turk, A. Wheeler and K.R. Clarke. 2002. Immigration of southern fish species to south-west England linked to warming of the North Atlantic (1960-2001). J. Mar. Biol. Ass. UK, 82: 177-180.

Welleman, H.C., S. Verver, J.J. Poos, A.E. Eltink and A.D. Rijnsdorp. - 2001. Changes in spatial distribution of sole Solea solea (L.), in relation to changes in temperature conditions in the North Sea. ICES Symposium on Hydrological Variability in the ICES area, 1990-1999. Edinburgh, Scotland, 8-10 August 2001 (poster).

Wheeler, A. - 1978. Key to the fishes of northern Europe. Frederick Warne (publishers) Ltd London, Great Britain.

Whitehead, P.J.P., M.-L. Bauchot, J.-C. Hureau, J. Nielsen and E. Tortonese. - 1986. Fishes of the north-eastern Atlantic and the Mediterranean. Part III. UNESCO, Paris.

Received June 1, 2002. Accepted November 24, 2004. 